\title{
Mobile Textula: A Possible New Way of Reawakening the Marginalized Philippine Poetry
}

\author{
Arjem Noryn C. Agum \\ Adventist University of the Philippines \\ ancagum@aup.edu.ph
}

\begin{abstract}
Poetry has long been part of any cultural and literary heritage. Despite poetry's role in Philippine literature, the 21st-century Filipino learners lack the knowledge about folk poetry. Poems sent through short messaging service (SMS) or mobile textula were then introduced to capture the interest of the Filipino millennial learners. However, studies say little about this emerging means of literary propagation. Anchored in the Social Construction of Technology (SCOT) Theory, this study aimed to contribute to the body of knowledge to reawaken the marginalized Philippine poetry. Through external desk research, this qualitative study delved into the history, type, sample poems, and the possibility of using mobile textula to reinforce the 21st-century Filipino learners' understanding of the marginalized Philippine poetry. After an integrative literature review of various sources (full paper in conference proceedings, journal articles, education-related sites, and online news), it was found that mobile textula was made known in 2002 through the "Textanaga Contest," the first text-a-poem contest in the Philippines which gathered 10,000 poems on its launching day. Sample poems were that of the tanaga, dalit, and diona which are considered marginalized poetry among the generation of modern Filipinos. Moreover, a private college in one of the provinces in Luzon saw the effectivity of textula in teaching language, literature, and socio-cultural awareness. Therefore, the study suggests that teachers consider the use of textula in teaching literature. Further, a wide scope of an experimental study on the effectiveness of textula in the classroom is recommended.
\end{abstract}

Keywords: Textula, Mobile Textula, Tanaga, Philippine Poetry, Marginalized Poetry

\section{INTRODUCTION}

People have different ways of expressing their moods and feelings. There are individuals who vent their emotion through arts, others through music, while some through poetry, to name a few. Nowadays, poetry is not only used as an expression but as a means of learning. Some educators, such as Schoch (2013), advocate considering poetry as part of a teacher's curriculum using it as a vital element in language, reading, and writing. Stovall (2006) believed that because the young people of today look for modern ways of class engagement, spoken word 
poetry about social justice may help them become more responsible individuals through a participatory process.

Poetry has always been part of the identity of each nation. However, Slinn (1999) stated that poetry gradually turns out to be a marginalized genre. A study in Australia affirmed that poetry is a genre that is at risk of becoming extinct to learners (Dymoke, 2012). Consequently, Gill (2011) argues that poetry should not be taught to children as a collection of the "classics" which has complicated meanings but rather a part of literature that expresses "thoughts, feelings, and experiences".

Poetry is believed to play a critical role in the culture of every civilization. Poetic language, according to Dowdy (2007), is a powerful language that speaks against discrimination, prejudice, hostility, indigence, and repression. Cultural differences, uniqueness, and identity are evident in arts and literature. Tales, poetry, politics, and social commentaries tell the culture of one's country, thus, allowing both cross-cultural enlightenment and prejudices to occur (Ten, 2011).

Nowadays, mobile phones are not only being used to disseminate short messages; they are also becoming an avenue to share quotations, verses, short inspirational messages, and poetry. In a study presented by Coroza (2012), it was found out that there seemed to be "a promising relation" between Philippine poetry and mobile phones through short messaging services (SMS). Therefore, this study was conducted to explore the possibility of using a mobile phone to reawaken the marginalized Philippine poetry.

\section{LITERATURE REVIEW}

\section{History of Poetry in the Philippines}

Guangco (2017) mentioned four literary periods of Philippine literature from the pre-Hispanic era up to present. In the pre-colonial period (years before 1521), town folks made use of oral transfer of literature passed on from one generation to the next. Oral literature included riddles and proverbs, folk songs, and folk tales.

During the arrival of the Spaniards in 1521, Christian themes emerged since the Spanish colonizers' major contribution in the Philippine culture and practice is Christianity or Catholicism (Becky326, 2017). Religious, secular or non-religious, propaganda, and revolutionary were the kinds of literature introduced during this era.

Upon the arrival of the Americans in the 1900s, new changes occurred in the Philippine literature (Borade, 2018). Guanco (2017) mentioned that since education was emphasized in 
the American era, literature has become an imitation of the American model. Instead of becoming original writers, students followed the forms and styles of American poets and writing free verse has become a norm.

The period of contemporary literature or new society started in 1972 (Estroga, 2016). Filipino poets in this period focused on the country's progress with themes dealing on patience, regard for native culture and customs, and the beauty of nature which gradually evolved on romantic and revolutionary themes (Estroga, 2016). Estroga (2016) emphasized that contemporary poets are straightforward in their criticisms using "fiery, colorful, violent, profane, and insulting language."

\section{Types of Philippine Folk Poetry}

The following types of poetry are only three of the many kinds existing in Philippine literature. However, the author opted to discuss only the three types related to the topic at hand. Originally, folk poems were called Awit for they were sung instead of simply being spoken (Angeles, 2014).

Tanaga. Tanaga is a short poem with four lines and seven syllables rhyming at the end of every line (Becky326, 2017). It is the oldest form of poetry in the Philippines (Nadera, 2006). Tanaga is the Philippine counterpart of the Japanese haiku (Baes, 2002) but unlike haiku, it has measure and line and has an allegorical meaning (Cudia, 2011). According to Shim'onai (2012), tanaga traditionally contained philosophical ideas and views about different issues in the world that would have been used by pre-Filipinos to teach morals to the younger generations together with myths. Moreover, traditional tanagas did not have titles for they were made to speak for themselves while the modern tanagas have title as opted by contemporary authors.

Dalit. Dalit is another type of short Filipino poem comprised of four lines with eight syllables each line. There was still an ongoing debate regarding the origin of dalit. Some say that the poem was pre-Hispanic in nature that was only popularized by the Spanish colonizers to advertise Catholicism, while others believed that it is Spanish in origin (Castro, 2011).

Diona. Diona is a wedding song consisting of three lines with eight syllables each line (Tagalog Lang, 2002). Moreover, it was used as a dramatic wedding song in the old days (Castor, 2019). Diona was believed to be existing even before the occupation of the Spanish in the Philippines. There was no database or registry of diona from the Unang 800 Sagisag Kultura ng Filipinas (first 800 Cultural Emblem of the Philippines) as introduced by the Filipinas Institute of Translation and National Commission for Culture and Arts (Angeles, 2014). 


\section{Reawakening Philippine Literature}

According to Chikiamco (2012), oral arts in the Philippines are not fixed; it means that there is a tendency for them to be extinct for they come and go. Hence, Herminia Coben, a Filipina writer, tried to transform the oral culture into "permanent print" (Barbaza, 2013; Chikiamco, 2012). This is one way to ensure the perpetuity of marginalized Philippine culture.

Furthermore, Eugenio (2007) suggested that instead of extinguishing oral literature, students, especially urban dwellers, should be made familiar with it, which could be achieved through printed items. However, now that the world faces the fourth industrial revolution age, a more advanced approach of inculcating the marginalized literature, in this case, Philippine poetry, should be carried out.

\section{Theoretical Framework}

Social Construction of Technology (SCOT). Pinch and Bijker (1984) saw the need to integrate social constructivism to science and technology; hence, the development of this theory. SCOT is a theory that studies the "technical change in the society" and the relationship "between society and technology" (Bijker, 2001). Gale (2005) emphasized that SCOT talks about how different social factors affect and mold technological advancements and changes. Moreover, SCOT offers a basis for comprehending the numerous influences that may affect the integration process (Peia, 2010).

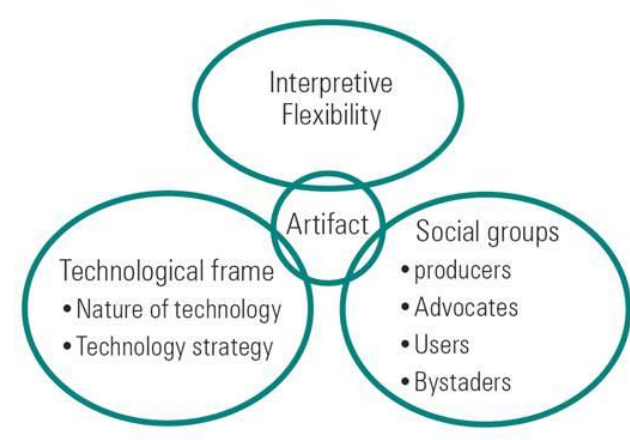

Figure 1. Social Construction of Technology Theory (Pinch \& Bijker, 1984).

\section{METHODS}

This study is qualitative in nature which utilized external desk research to exhaust any available information about mobile textula. The history, types, sample poems, and the possibility of using mobile textula to reinforce the 21 st-century Filipino learners' understanding of the 
marginalized Philippine poetry were delved into by reading various sources related to the topic. Aside from the readings connected to Philippine literature and poetry, an integrative literature review of various sources (full paper in conference proceedings, journal articles, educationrelated sites, online news, and a personal conversation) was done to saturate the sufficient details that fulfilled the objectives of the study.

\section{RESULTS}

Among the many uses of mobile phones, Goodman (2019) mentioned that learning and research is one. Lieberman (2019) cited that in a survey done in 2018 among 1500 online students, $80 \%$ mentioned that they finish most of their courses with the use of mobile phone while $40 \%$ mentioned that they do their research for reports using their smartphones. However, Leiberman (2019) also noted in a separate survey that among 44,000 students $70 \%$ revealed that their teachers ban the use of smartphones in the classroom. In the fourth industrial revolution era where technology is advancing at a fast pace, the use of mobile phones as learning and teaching tool is apparent.

The potential of SMS teaching approaches in the formal and non-formal schools in the Philippines and Mongolia was found to be accepted by students and trainees (Librero, Ramos, Ranga, Triñona, \& Lambert, 2007). In connection, Jin and Sabio (2018) found in a study in Manila that there is a need to update school policies and curricula to cater the mobile era learners.

\section{History of Mobile Textula}

Textpoem is not new. For years, some poets utilize mobile phones to send poems. Tracey (2019) simply put textpoems as "a poetry that fits inside a text message"; limited to up to 160 characters. Moreover, the poem should be composed on the mobile phone and be sent to at least one recipient. The use of mobile phones to share a nation's literary art was said to have started in Japan through mobile phone novels (Ulat, 2017). Its popularity has reached internationally, especially in China, the United States, Germany, and South Africa among others.

The Guardian pioneered a mobile text poetry competition in 2001 which aimed to turn mobile texting into a creative platform and was able to gather almost 7,500 entries from 4,700 mobile phones (Keegan, 2001). In Leeds, United Kingdom, an organization encouraged Leeds' mobile phone users to take part in their yearlong activity of interactive poetry in 2003 which they 
called CityPoems. The mobile phone users are encouraged to tell somebody, through mobile poetry, a personal landmark or personal life experience in Leeds (Noema Lab, 2003).

Textpoems may have been used in the Philippines decades ago, but it was made known to many only when Nadera, a poet, fictionist, playwright, and essayist, led the Poetry Therapy among cancer patients in the Philippines. The positive results and the alleviation of cancer among patients pushed Nadera to initiate other uses of poetry to help fellow Filipinos; one of the developments was the promulgation of Mobile Textula Contest (CCP Literary Arts Division, n.d.).

Textula is the genre of poetry read in mobile phones and has originated as a traditional Tagalog version of haiku, which is the tanaga (Aldeguer, 2017). Mobile textula was introduced in the Philippines in a way of an annual contest since 2002. The University of the Philippines' Institute of Creative Writing (UP-ICW), in 2002, (Orillos, 2005) founded the first text-a-poem contest in the Philippines (Nadera, 2007) which initially introduced Textanaga. Through the cooperation of the National Commission for Culture and Arts (NCCA), UP-ICW added Dalitext. The interview done by Gardner (2006) with Luisa Igloria, a renowned Filipina writer, affirmed that projects to encourage awareness among Filipino youth regarding folk poetry were being held in the Philippines. One idea is sponsoring a contest that requires participants to submit an original tanaga, diona, or dalit through mobile phones. This effort helped the young people to be familiar with the aforementioned folk poetry.

The proponents of Mobile Textula took "advantage of the Filipinos' fancy" in mobile texting and the use of technology (Cristobal, 2004). Using a mobile phone as a medium for poetry to be fun and in trend, mobile textula became a hit among Filipino poets and aspirers (Tablada, 2016). An estimated 50 million text messages were sent by Filipinos every day, worldwide (Nadera, 2006). Nadera (2007) added that in 2003, the Mobile Textula Contest was able to gather 10,000 tanaga entries and 30,000 dalit entries submitted by different participants. The contest became a hit that in 2004, aside from the tanaga and dalit entries, 40,000 diona entries were added and submissions do not only come from Filipinos in the Philippines; there were entries from Qatar, Kuwait, Riyadh, Bahrain, and Hong Kong. This popularity made the organizers produce an anthology of textanaga, dalitext, and dionatext (Wengwengliterature, 2017). Entries gradually increase each year that the contest was being anticipated especially in the February Arts Month celebration.

The Mobile Textula Contest was introduced in the "information and communication technology" era to learn Philippine literature in a fun way (Orillos, 2005). Santos (2011) 
reported that the success of Mobile Textula Contest from inspired the Linangan sa Imahen, Retorika, at Anyo (LIRA) of UP Diliman to utilize Facebook as an alternative platform for sharing Philippine poetry through another contest called Tulaan sa Facebook. Unfortunately, in a personal conversation with the Foundation for Advancing Wellness, Instruction and Talents (AWIT, August 4, 2019), the researcher found out that the contests "are no longer running." The researcher tried to reach out to the UP-ICW since June 2019 and confirm the matter, but there was no response from the institution. Therefore, the reasons behind the discontinuation of the contests are still unknown.

\section{Type of Mobile Textula}

Textanaga. Text entries for the Textanaga Contest are original tanagas which are a four-liner poem with seven syllables each (Nadera, 2007).

Dalitext. Text entries for the Dalitext Contest are original dalits which are also a four-liner poem but with eight syllables per line (Nadera, 2007).

Dionatext. Text entries for Dionatext Contest are original dionas which are a three-liner poem with seven syllables per line (Nadera, 2007). Diona is one of the oldest poems in Philippine literature that is being reawakened among Filipinos, not through ink but SMS (Orillos, 2005). Castor (2019) cited that Dionatext was developed for teachers to follow the progress of technology.

\section{Sample Poems}

Textula writers make use of one slant (/) to signify the end of a line, and two slants (//) to end a stanza (Tablada, 2016). Furthermore, as mentioned by Shim'onai (2012), folk poetry has no title for they tend to convey their own meanings; hence, most of the mobile textulas have no titles although some writers still opt to give titles on their work.

Textanaga. Isang payapang araw/ kalaro'y hinahanap/ may batang nakadungaw/ sirang manika yakap// Tanging bilin ni inay/ siya ay wag lapitan/ sapagkat di kapantay/ iba ang kinagisnan// (Enriquez as cited in Aldeguer, 2017). This poem talks about a child looking for her playmate and she saw a girl looking out of the window holding a broken doll; however, this child was told by her mom not to get near the girl because they have different life status.

Puto lang ako sinta/ may init ng bibingka/ tamis ng maja blanca/ sapin-saping ligaya// (Francisco as cited in Nadera, 2006). Through metaphors, the speaker of the poem described love as simple, warm, sweet, and full of joy as the numerous varieties of Philippine rice cakes. Dalitext. Di pa hinog sa panahon/ tinutuka na ng ibon/ bungang natakpan ng dahon/ sinusungkit na ng gutom// (Rivera as cited in Nadera, 2006). This poem tells that even if a fruit 
is not yet ripe, the birds eat it already; even if a fruit is hidden behind a leaf, a hungry person gets it.

Buhok man ay nagkulay tsok/ lalamunan ma'y napaos/ walang lubay sa paghubog/ng magiging manunubos// (Bajado as cited in Nadera, 2006). The poem is about the life of teachers. They don't care if their hair turns chalk-like in color or lose their voice in talking; they will not get tired of shaping the future liberators.

Napakasarap pakinggan/mahal ko ang aking bayan/ mas masarap maulinigang/ ginagawa ang naturan// (Rodillo as cited in Nadera, 2006). This poem speaks of true love for the country. Though it is pleasant to hear that someone loves his/her country, it is better to see that love in action.

Dionatext. Ang payong ko'y si Inay/ Kapote ko si itay/ Sa maulan kong buhay// (Pambid as cited in Orillos, 2005). This poem tells that in life's rains, mothers serve as umbrellas and fathers are the raincoats. This implies that parents are the best shield in someone's struggles and challenges.

Anak na nagkamali/ Kung ngayo’y sasangguni/ Yayakapin ding muli// (Castor, 2019). Finally, this poem talks about how unconditional parents' love is for their children. Though children make mistakes, if they come to their parents, they will still be welcomed with a warm embrace.

\section{Possibility of Mobile Textula Usage in Literature Class}

Students of this generation are the major users of technology. It is more convenient for students to bring their smartphones in school rather than their laptops; hence some lecturers and teachers use smartphones as the learning aids in class (Anshari, Almunawar, Shahrill, Wicaksono, \& Huda, 2017). In their study, Anshari et al. (2017) found out that the use of mobile phones, specifically smart phones, improves the students' communication and interaction, furthers the utilization of multimedia, and fosters multiple functions during class both for teaching and learning.

With the diversified purpose of mobile phones in teaching and learning in the Philippines, being a medium to teach and learn Philippine poetry can be included. As initialized by the Mobile Textula Contest, the main objective is to "popularize and revitalize the tradition of the oldest forms of Filipino poetry by using modern technology" (Panitikan Philippine Literature Portal, 2014). In the hope to bring awareness and appreciation of traditional poetry among fellow Filipinos, Nadera spearheaded the Mobile Textula Contest (Anonas-Carpio, 2005). Popularizing Philippine literature programs aimed to teach in the different provinces of the Philippines and provide a training center in UP Diliman. The organizers understand that not all 
aspiring Filipino poets and writers can afford to go to Manila for proper training; hence, these programs were introduced (Santos, 2011). Utilizing social media and mobile phones as platforms for the reawakening of marginalized Philippine poetry may restore the identity of the Philippine poetry's original form; that the old form can still get along in a technological era (Santos, 2011).

Using SMS as an avenue for reawakening the Filipino's literary heritage may function as a springboard to the study of Philippine literature and arts and may create modern literary talents that can integrate folk poetry to modernity (Orillos, 2005). The three mobile textulas were shortened versions of folk poetry that were abruptly relived for the masses through mobile texting contest (Castor, 2019). The Unyon ng mga Manunulat sa Pilipinas (UMPIL) hoped that one of the big mobile phone companies in the Philippines considers sponsoring prizes for the perpetuation of this unique mobile phone contest (Yuson, 2003).

A Filipino Language and Literature teacher in a private college in Cavite, Philippines, who happened to be a regular contestant and winner of the Mobile Textula Contests, imitate the same endeavor in the school where he/she teaches. It was found out that the administrators, coteachers, and students extend their support to the project for they see that textula has been an effective way to teach "language, literature, and socio-cultural awareness" (Coroza, 2012). However, Aldeguer (2017) pointed out that mobile textula does not need to be a literary contest entry; it can simply be a piece of Philippine literature that Filipinos can share through mobile texting. The step taken by the UP-ICW and NCCA paved the way for modern Filipinos to merge the old with the new to get connected with fellow-Filipinos (Cristobal, 2004). In the long run, short versions of poems other than tanaga, dalit, and diona, as long as they have meters and rhymes, can be mobilized through phone (Tablada, 2016).

\section{DISCUSSION}

In an interview done by Philstar Global with Nadera, it was mentioned that mobile textula is just the beginning; in the future, there could be a possibility of having Textalingdao, Textigpasin, and Textagumpay. Since technological advancement cannot be controlled, it might also be possible to have Discussionboarduplo, Hologramabahan, Faxsidai, E-mailaji and Chatigsik (Anonas-Carpio, 2005). In an article written by Coroza (2017), the success of Textula for more than a decade has been evident. Creating poems with the use of traditional forms is an innovative utilization of mobile phones. In more than a decade, there have been approximately 100,000 textpoem entries sent as of the year the article was published. Mobile 
textula could probably be "the dawning of the age of literary technology" in the Philippines (Anonas-Carpio, 2005).

Based on the findings, it is recommended that government and non-government organizations, private sectors, and philanthropists support the literary endeavors of different institutions and groups who provide opportunities for Filipino writers, student poets, and aspirers to develop their literary skills. Moreover, literature teachers of the fourth industrial revolution era should be open-minded in welcoming changes brought about by technological advancement. Finally, a wide scope of an experimental study on the effectiveness of textula in the classroom is recommended.

\section{Conclusion}

In an era of technological advancement, the integration of the traditional to the modern world is still achievable. Individuals, organizations, and institutions have been finding ways to do so. Mobile textula was one route to wider avenues of merging possibilities to reawaken, revitalize, and popularize the almost-forgotten genres of Philippine literature. In the future, opportunities of utilizing facsimile, electronic mails, chats, discussion boards, holograms, online classrooms, and other technological inventions and developments to promote cultural identity, social responsibility, and moral character of students, can be made possible

\section{REFERENCES}

Aldeguer, T. (2017). Textula. Retrieved from https://prezi.com/3nhoq2lndlz1/textula/

Angeles, M. (2014). Diona. Pinoy Weekly. Retrieved from https://www.pinoyweekly. org/2014/05/diona/

Anonas-Carpio, A. (2005). Techno-literature a la pinoy. Philstar Global. Retrieved from https://www.philstar.com/business/telecoms/2005/05/14/277518/techno-literature-lapinoy

Anshari, M., Almunawar, M.N., Shahrill, M., Wicaksono, D.K., \& Huda, M. (2017). Smartphones usage in the classrooms: Learning aid or interference? Education and Information Technologies, 22(6), 3063-3079. Retrieved from https://link.springer.com/article/10.1007/s10639-017-9572-7

Baes, E.P. (2002). Tanaga, the Filipino haiku. Retrieved from https://www. tagaloglang.com/tanaga-filipino-haiku-poems/

Barbaza, R.E. (2013). Verbal arts in Philippine indigenous communities: Poetics, society, and history by Herminia Meñez Coben (review). Philippine Studies: Historical and Ethnographic Viewpoints, 61(2), 251-254. doi:10.1353/phs.2013.0005 
Becky326 (2017). Philippine literature poetry. Retrieved from https://www.slideshare.net /becky326/philippine-literature-poetry-77425249

Bijker, W.E. (2001). Social construction of technology. International Encyclopedia of the Social \& Behavioral Sciences. Retrieved from https://www.sciencedirect.com/topics/ social-sciences/social-construction-of-technology

Borade, G. (2018). A quick look at the fascinating history of Philippine literature. Penlighten. Retrieved from https://penlighten.com/history-of-philippine-literature

Castor, F.B. (2019). Dionatext: Bagong anyo $n g$ panitikan sa panahon $n g$ teknolohiya. Retrieved from https://www.scribd.com/doc/262163045/Diona-Text and https://do kumen.tips/documents/diona-text.html

Castro, C. (2011). Musical renderings of the Philippine nation. New York, NY: Oxford University Press.

CCP Literary Arts Division (n.d.). Sangkomunidad: May-akda. Retrieved from http://lcommunity.tripod.com/mayakda4.html

Chikiamco, P. (2012). Asian ethnology review of verbal arts in Philippine indigenous community. Rocket Kapre. Retrieved from http://www.rocketkapre.com/2012/asianethnology-review-of-verbal-arts-in-philippine-indigenous-communities/

Coroza, M.M. (2012). Textula: Promoting Filipino folk poetry through text messaging. In the Proceedings of the $4^{\text {th }}$ International Conference on Language and Communication (December 13-14, 2012). Bangkok, Thailand: Graduate School of Language and Communication, National Institute of Development Administration.

Coroza, M.M. (2016, July 4). Pagtataguyod ng tula sa pagtetext. Pressreader. Retrieved from https://www.pressreader.com/philippines/liwayway/20160711/page/30/textview

Cristobal, P.R.G. (2004). In focus: Dionatext: Dissecting the winning entries. National Commission for Culture and the Arts. Retrieved from http://gwhsstg02.i.gov.ph/ s2govnccaph/about-culture-and-arts/in-focus/dionatext-dissectingthe-winning-entries/

Cudia, E. (2011). Philippine literature chapter 6. Retrieved from https://www.slideshare.net/cudiaeduardo/philippine-literature-chapter-6

Dowdy, M. (2007). American political poetry into the $21^{\text {st }}$ century. New York, NY: Palgrave Macmillan.

Dymoke, S. (2012). Poetry is an unfamiliar text: Locating poetry in secondary English classrooms in New Zealand and England during a period of curriculum change. Changing English: Studies in Culture and Education, 19(4), 395-410. https://doi.org/10.1080/1358684X.2012.736741 
Estroga, I.J. (2016). Philippine literature: The contemporary period. Retrieved from https://www.slideshare.net/josephestroga/philippine-literature-the-contemporaryperiod

Eugenio, D.L. (2007). Philippine folk literature: An anthology. Quezon City, Philippines: University of the Philippines Press.

Gale, T. (2005). Social construction of technology. Encyclopedia of Science, technology, and Ethics. Retrieved from https://www.encyclopedia.com/sciencelencyclopediasalmanacs-transcripts-and-maps/social-construction-technology

Gardner, C.A. (2006). History and the work of memory: An interview with Luisa A. Igloria. Virginia Libraries, 52(2). Retrieved from https://ejournals.lib.vt.edu/valib/article/ view/1010/1291

Gill, S.R. (2011). The forgotten genre of children's poetry. International Literacy Association: The Reading Teacher, 60(7), 622-625. https://doi.org/10.1598/RT.60.7.2

Goodman P. (2019). 20 advantages of mobile phones. Turbofuture. Retrieved from https://turbofuture.com/cell-phones/advantages-Mobile-Phones

Guanco, E.M. (2017). The Philippine literature history. Retrieved from https://www.s lideshare.net/augustianelijah/the-philippine-literary-history

Jin, W. \& Sabio, C.J. (2018). Potential use of mobile devices in selected public senior high schools in the city of Manila Philippines. International Journal of Learning, Teaching, and Educational Research, 17(4). https://doi.org/10.26803/ijlter.17.4.7

Keegan, V. (2001, May 3). The message is the medium. The Guardian. Retrieved from https://www.theguardian.com/technology/2001/may/03/internet.poetry

Librero, F., Ramos, A.J.O., Ranga, A.I., Triñona, J., \& lambert, D. (2007). Uses of the cell phone for education in the Philippines and Mongolia. Distance Education, 28(2), 231 244. DOI:10.1080/01587910701439266

Lieberman, M. (2019). Students are using mobile even if you aren't. Inside Higher Ed. Retrieved from https://www.insidehighered.com/digital-learning/article/2019/02/27/ mobile-devices-transform-classroom-experiences-and

Nadera, V. (2006). Textanaga and dalittext. Tagalog Poetry Indigenous Expressions. Retrieved from https://www.english-to-tagalog.com/Tagalog-poetry.html

Nadera, C.D. Jr. (2007). Speaking in tongues. Philippine Center for Investigative Journalism. Retrieved from https://pcij.org/stories/speaking-in-tongues/

Noema Lab (2003). City poems: SMS text message poetry 2003. Retrieved from https://n oemalab.eu/senza-categoria/city-poems-sms-text-message-poetry-2003/ 
Orillos, J.B. (2005). Connecting families through dionatext. Sanghaya. Retrieved from http://sanghaya.net.ph/welcome/2005/12/31/1014/

Panitikan Philippine Literature Portal (2014). Join textanaga connect. Likhaan: U.P. Institute of Creative Writing. Retried from http://panitikan.ph/2014/09/03/join-textanagaconnect/

Peia, M. (2010). Integrating the old with the New: Understanding the social construction of cell phone technology. Presented in the Undergraduate Humanities Forum 2009-2010. Pennsylvania: University of Pennsylvania. Retrieved from http://repository. upenn.edu/uhf_2010/15

Pinch, T.J. \& Bijker, W.E. (1984). The social construction of facts and artefacts: Or how the sociology of science and the sociology of technology might benefit each other. Social Studies of Science, 14(3), 399-441. Retrieved from https://research.utwente.nl/en/publications/the-social-construction-of-facts-andartefacts-or-how-the-sociolo

Santos, T.U. (2011). Panitikan sa panahon ng 'social networking'. The Varsitarian. Retrieved from https://varsitarian.net/filipino/20111115/panitikan_sa_panahon_ng_social _networking

Schoch, K. (2013). 10 ways to use poetry in your classroom. Reading Rockets. Retrieved from https://www.readingrockets.org/article/l0-ways-use-poetry-your-classroom

Shim'onai, Y.B.P. (2012). Tanaga: A Filipino treasure. Retrieved from https://truml .com/shimyonay/prose/112984

Slinn, E.W. (1999). Poetry and culture: performativity and critique. New Literary History, 30(1), 57-74. Johns Hopkins University Press. Retrieved July 16, 2019, from Project MUSE database.

Stoval, D. (2006). Urban poetics: Poetry, social justice and critical pedagogy in education. The Urban Review, 38(1), 63-80. https://doi.org/10.1007/s11256-006-0027-5

Tablada, R. (2016). Mobile phone textula. Retrieved from https://prezi.com/e-_ch4rzx8a/mobile-phone-textulal

Tagalog Lang (2002). Diona. Retrieved from https://www.tagaloglang.com/diona/

Ten, K.S. (2011). Contemporary poetry's influence on cross-cultural perceptions. Inquiries Journal: Social Sciences, Arts, \& Humanities, 3(2). Retrieved from http://www.inquiriesjournal.com/articles/394/2/contemporary-poetrys-influence-oncross-cultural-perceptions

Tracey, S. (2019). The art of texting: Composing text poems with Shelley Tracey. Inkwell. Retrieved from https://www.writing.ie/resources/the-art-of-texting-composing-textpoems-with-shelley-tracey/ 
Ulat, A. (2017). Mobile text tula. Retrieved from https://teslaliterature.wordpress.com /2017/08/17/mobile-text-tulal

Wengwengliterature (2017). Virgilio S. Armalio. Wordpress. Retrieved from https://weng wengliterature.wordpress.com/2017/11/27/virgillio-s-armalio/

Yuson, A.A. (2003). Singatoons \& textanaga. Philstar Global. Retrieved from https://w ww.philstar.com/lifestyle/arts-and-culture/2003/02/17/195759/singatoons-amp-textanaga 